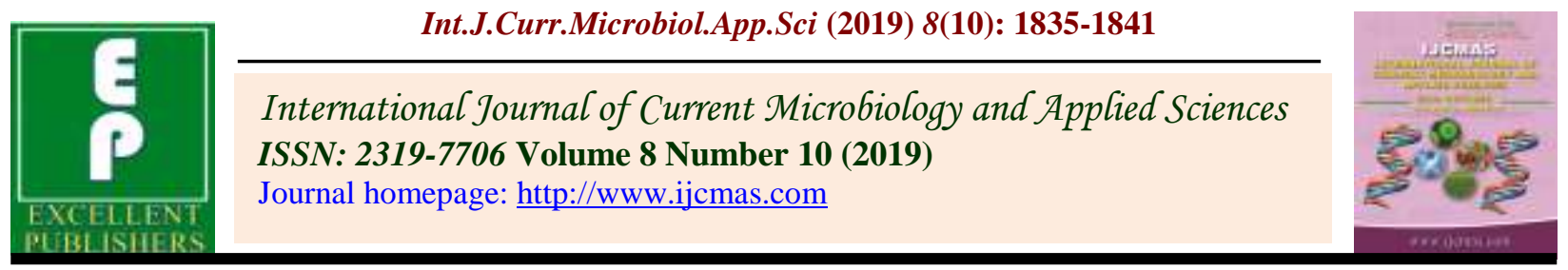

Original Research Article

https://doi.org/10.20546/ijcmas.2019.810.213

\title{
Inclusion of Lemongrass (Cymbopogon citratus) Leaf Meal as a Natural Feed Additive for Evaluation Serum Lipid Profile of Broilers
}

\author{
A. K. Parade, B. M. Thombre, R. A. Patil, P. V. Padghan, \\ S. S. Shinde and P. B. Meshram*
}

Department of Animal Husbandry and Dairy Science, College of Agriculture, Latur, India

*Corresponding author

\begin{tabular}{|l|}
\hline Ke y w or d s \\
Body weight, \\
Serum lipid profile \\
\hline Article Info \\
\hline $\begin{array}{l}\text { Accepted: } \\
\text { 15 September } 2019 \\
\text { Available Online: } \\
\text { 10 October } 2019\end{array}$ \\
\hline
\end{tabular}

A B S T R A C T

An experiment was conducted on the effect of lemongrass leaf meal as a natural feed additive on the growth performance, serum lipid profile of broiler chickens. Eighty, day-old broiler chicks (Vencobb-430) were randomly divided into four equal groups containing 5 replicates of 20 chicks were offered a standard broiler diet $\left(\mathrm{T}_{1}\right)$ and lemongrass leaf meal supplemented diet @ $0.5 \%\left(\mathrm{~T}_{2}\right), 1.0 \%\left(\mathrm{~T}_{3}\right)$ and $1.5 \%\left(\mathrm{~T}_{4}\right)$ on dry matter basis by partial of control diet for 42 days. Incorporation of LGLM at both $1.5 \%$ level significantly $(\mathrm{P}<0.05)$ improved the body weight and feed efficiency and serum profile and economics of broilers production. There was significant $(\mathrm{P}<0.05)$ serum total cholesterol, triglyceride, in LGLM supplemented birds. However, nonsignificant $(\mathrm{P}>0.05)$ variation was observed in cholesterol, HDL-cholesterol, LDL-cholesterol LDL/HDL ratio and total protein in diet. The results from the present study, it could be suggested that the use of LGLM as a feed additive at the level of 1.5 per cent as it improved the significantly better growth performance, serum lipid profile of broiler production was increased.

\section{Introduction}

The recent trend in the feed supplement is directed toward the use of natural ingredients as alternatives to antibiotics, synthetic colors and other chemicals. Feed additives are added to broilers diet to improve its productive performance by increasing growth rate, better feed conversion efficiency and greater livability in poultry birds. Leafy vegetables seed powder as an additive in the diet of chickens is very common. Lemongrass is an aromatic perennial tropical plant that can grow as high as 3.5 meters with long thin leaves. Lemon grass was originally found growing wild in India. It produces a network of roots and rootless that rapidly exhausts the soil. In human medicine, Lemongrass has the 
following therapeutic properties: analgesic, antidepressant, antimicrobial, antipyretic, antiseptic, bactericidal, diuretic, fungicidal, insecticidal and nervous system sedative tonic (Mmereole 2010). Lemongrass (Cymbopogon citratus) contains flavonoids, phenolic compounds, terpenoids and essential oils (such as citral $\alpha$, citral $\beta$, nerol geraniol, citronellal, terpinolene, geranyl acetate, myrecene and terpinol methylheptenone) which may be responsible for its different biological activities such as anti-bacterial, anti-diarrheal, anti-fungal anti-oxidants, and as a growth promoter (Sariozkhan et al., 2016).

Chemical composition and anti-bacterial activity of aqueous extract of Cymbopogon citratus leaves were studied. Moisture, Crude protein, Crude fiber and Carbohydrate contents were $12.36 \%, 15.68 \%, 27.72 \%$ and $29.58 \%$ respectively. Phosphorus was found to be the most abundant $(15.58 \mathrm{mg} / 100 \mathrm{~g})$ followed by Potassium (8.60mg/100g). Zinc an important microelement was present in considerable amount $(0.93 \mathrm{mg} / 100 \mathrm{~g})$ (Oloyede 2009). Lemon grass it is believed that some of these advantages can be harnessed and brought to bear generally in livestock production and particularly in broiler production to enhance growth and the overall production performance and thus replace the antibiotic growth promoters. There are numerous feed additives of plant origin that are used in broiler feeds to improve the performance by enhancing growth rate, better feed conversion efficiency and lower mortality. Recently, the use of antibiotics as feed additives is contra-indicated due to health concern about their residues in animal tissues and the production of drug resistant bacteria (Zomrawi et al., 2012).

\section{Materials and Methods}

Eighty, day old, commercial straight run broiler chicks of 'vencobb 430' strain were obtained from Huma hatcheries, Latur (Maharashtra). All the experimental chicks were individually weighed and banded and then randomly distributed in to four treatments of 20 chicks with four replication of 5 chicks in each treatment on similar body weight basis The dietary treatments $\mathrm{T}_{1^{-}} 100$ parts of standard broiler ration without supplement (control sample), $\mathrm{T}_{2^{-}} 99.5$ parts of standard broiler ration +0.5 lemongrass leaf meal, $\mathrm{T}_{3^{-}}$ 99.00 parts of standard broiler ration +1.00 parts of lemongrass leaf meal and $\mathrm{T}_{4^{-}} 98.5$ part standard broiler ration +1.5 parts of lemongrass leaf meal. All the broiler chicks were fed with ground maize first two days of age. Chicks feed standard feed purchased from market for three periods of 2-10 days birds fed with pre-starter, 11-21 days birds fed with broiler starter and 22-42 days birds fed with broiler finisher. The diets were fed ad-libitum to experimental groups by adding required amount of lemongrass leaf meal as per treatment. The per cent ingredient composition of experimental broiler ration that is for prestarter, starter and finisher in Table 1.

\section{Collection of blood}

At the end of experiment three ml blood was collected from wing vein in syringe without any anticoagulant and kept in clot activator tubes. The serum constituent's parameter were determined by local pathological laboratories and diagnostic institute and estimated the following blood serum parameters. Serum constituent's estimation of Glucose, Serum Cholesterol, Serum Triglycerides, Serum HDL i.e. (High density lipoprotein), Serum LDL i.e. (Low density lipoprotein), LDL/HDL Ratio, Blood Protein, Albumin and Globulin.

\section{Chemical analysis}

The chemical analysis of the experimental broiler ration was carried out as per A.O.A.C. (1995) for all the proximate principles. 


\section{Statistical analysis}

The treatment wise data on cumulative body weight gain in body weight, feed consumption and feed conversion ratio and blood serum constituents were subjected to analysis of variance of complete randomized design (Snedecor and Cochran, 1982).

\section{Results and Discussion}

\section{Cumulative body weights}

The experimental bird's body weight at weekly interval from day initial to sixth week is presented in Table 2. The data on the growth performance of the cumulative body weight of experimental broiler birds under various experimental treatments are recorded during the sixth weeks were subjected to CRD and the results are presented in Table 2.

The statistical analysis on the weekly body weight of broiler birds under four different treatments during each week revealed significant $(\mathrm{P}<0.05)$ difference during all the weeks except initial, first and second week. At the end of sixth week the sixth week it was observed from Table 2 that the average cumulative body weights of broiler birds in the treatment group $\mathrm{T}_{4}$ and $\mathrm{T}_{2}$ were significantly $(\mathrm{P}<0.05)$ higher as compared to those in $T_{1}$ whereas at par with $T_{3}$ group. The average body weight of obtained in $\mathrm{T}_{4}$ group was significantly superior over $\mathrm{T}_{1}$. Body weight gain by birds in $\mathrm{T}_{2}$ group did not differ significantly from $T_{3}$ and $T_{2}$ and $T_{4}$ was at par with each other. The body weight of treatment $\mathrm{T}_{1}$ Control was significantly lower as compared to the treatments i.e. $\mathrm{T}_{2}$ and $\mathrm{T}_{4}$. The increase level of growth pattern indicated that optimum beneficial effect of lemongrass leaf meal supplementation as an herbal feed additive could be achieved at 1.5 per cent level of inclusion. The improvement in body weights of birds in all lemongrass leaf meal diet groups was observed. It may be due to the presence of flavonoids, phenolic compounds, terpenoids and essential oil which may be responsible for its biological activities such as antibacterial, antidiarrheal, antifungal, antioxidants and growth promoter. The results of the present study ware similar with Mmereole (2010) who observed that inclusion of Cymbopogon citratus leaf meal in poultry diet resulted in a significantly $(\mathrm{P}<0.05)$ higher body weight and body weight gain when compared to the control diet. Similar trend was also observed by Weerasingha and Atapattu (2013) who reported the same result as the weekly live body weight of fenugreek fed 1 per cent fenugreek seed powder group of broiler remained significantly $(\mathrm{P}<0.05)$ higher than that of control group. Similar trend was also observed by Tiwari et al., (2018) who found that total weight gain of birds was higher in experimental birds receiving lemongrass oil as compared to control group without lemongrass oil.

Lemongrass is herb and proved to have health and medicinal benefits. This grass contains flavonoids, phenolic compounds, terpenoids. Lemongrass could be used as an alternative to antibiotics. The lemongrass metabolites as oil (LGO) is considered as a viable alternative to antibiotics for the broiler and have been studied as an alternative for microbial and growth promoting abilities in the poultry, and that resulted minimized feed expense in the production chain it helps to promote the body weight of broilers.

\section{Serum lipid profile}

The average mean of serum constituents like glucose, cholesterol, triglyceride, high density lipoprotein (HDL), low density lipoprotein (LDL) HDL and LDL ratio, total protein, albumin and globulin of broilers as influenced of dietary inclusion of lemongrass leaf meal it was estimated at the end of experiment and the 
results are presented in Table 3 Results shows the result of serum lipid profile of the broiler chickens fed varying levels of lemongrass leaf meal. It was observed that all the serum lipid profile parameters differs significantly $(\mathrm{P}<0.05)$ except cholesterol, HDL, LDL, HDL and LDL ratio and protein which had no significant difference $(\mathrm{P}>0.05)$ among the dietary treatment.

Also results indicated that the concentration of glucose increased as the level of lemongrass leaf meal increased in the diet, the difference level of glucose in $\mathrm{T}_{4}$ was significantly $(\mathrm{P}<0.05)$ more as compared to $\mathrm{T}_{1}$ and $\mathrm{T}_{2}$, whereas at par with treatment $\mathrm{T}_{3}$. The differences level of cholesterol in $T_{1}, T_{2}, T_{3}$ and $\mathrm{T}_{4}$ were non-significant. Which indicated that the concentration of cholesterol decreased in $1.5 \%$ inclusion of lemongrass leaf meal. This suggests that the presence of antihypertensive compounds such as flavonoids and alkaloids present in Cymbopogon citratus has reduced serum cholesterol thereby preventing cardiovascular disease. Similar observations HDL (High density lipoprotein) (mg/dl), LDL (Low density lipoprotein) $(\mathrm{mg} / \mathrm{dl})$ were also found by Chioma et al., (2017) who reported that the concentration of cholesterol level treatment $0.2 \%$ Cymbopogon citratus had the lowest value.

There were significantly increase $(\mathrm{P}<0.05)$ but numerically decreased the cholesterol level of the serum in the treatment groups. The inclusion of fenugreek seed powder in broiler ration substantially decreased the serum cholesterol. Gaikwad (2018) also reported that the concentration of cholesterol decreased in $1.5 \%$ inclusion of fenugreek seed powder.

Triglyceride was highest in $\mathrm{T}_{4}$ and lowest in $\mathrm{T}_{1}$ i.e. $\mathrm{T}_{4}$ group with supplemented lemongrass leaf meal which had significantly $(\mathrm{P}<0.05)$ higher level of serum triglyceride than other three groups. The HDL was highest in $\mathrm{T}_{4}$ of $1.5 \%$ level of lemongrass leaf meal and lowest value in $\mathrm{T}_{1}$ in control group. The values of HDL clearly showed that all supplemented lemongrass leaf meal treatments had higher values than control.

Table.1 Chemical composition of experimental broiler ration

\begin{tabular}{|c|c|c|c|c|}
\hline \multirow{2}{*}{ Sr. } & \multirow{2}{*}{ No. } & Nutrients & \multicolumn{3}{|c|}{ Per cent in ration } \\
\cline { 3 - 5 } & Pre-starter & Starter & Finisher \\
\hline $\mathbf{1}$ & Crude protein & 23.35 & 21.64 & 20.20 \\
\hline $\mathbf{2}$ & Crude fibre & 3.92 & 3.96 & 3.99 \\
\hline $\mathbf{3}$ & Ether extract & 4.95 & 5.08 & 5.12 \\
\hline $\mathbf{4}$ & Total ash & 6.2 & 6.1 & 5.93 \\
\hline $\mathbf{5}$ & Acid insoluble ash & 1.57 & 1.60 & 1.62 \\
\hline $\mathbf{6}$ & Nitrogen free extract & 61.58 & 63.22 & 64.76 \\
\hline $\mathbf{7}$ & Metabolizable energy $(\mathrm{kcal} / \mathrm{kg})$ & 2982.5 & 3065.7 & 3198.8 \\
\hline $\mathbf{8}$ & E/P ratio & $127.73: 1$ & $141.66: 1$ & $158.35: 1$ \\
\hline
\end{tabular}


Table.2 Cumulative body weight of broiler chicks as affected by addition of lemongrass leaf meal

\begin{tabular}{ccccccc}
\hline & Items & \multicolumn{5}{c}{ LGLM levels } \\
\hline & & $\mathrm{T}_{1}$ & \multicolumn{1}{c}{$\mathrm{T}_{2}$} & \multicolumn{2}{c}{$\mathrm{T}_{3}$} & \multicolumn{2}{c}{$\mathrm{T}_{4}$} \\
\hline$(0 \%)$ & $(0.5 \%)$ & $(1 \%)$ & $(1.5 \%)$ & $\mathrm{SE}$ & $\mathrm{CD}$ at $5 \%$ & \\
\hline Initial & 46.97 & 47.41 & 47.42 & 47.23 & 0.147 & $\mathrm{NS}$ \\
\hline $1^{\text {st }}$ week & 166 & 170.79 & 149.50 & 197.83 & 14.78 & $\mathrm{NS}$ \\
\hline $2^{\text {nd }}$ week & 362.00 & 382.01 & 349.00 & 415.25 & 20.67 & $\mathrm{NS}$ \\
\hline $3^{\text {rd }}$ week & $682.225^{\mathrm{a}}$ & $818.50^{\mathrm{bc}}$ & $799.67^{\mathrm{b}}$ & $883.99^{\mathrm{c}}$ & 23.75 & $*$ \\
\hline $4^{\text {th }}$ week & $1214.50^{\mathrm{a}}$ & $1333.50^{\text {bc }}$ & $1285.00^{\mathrm{ab}}$ & $1371.72^{\mathrm{c}}$ & 23.81 & $*$ \\
\hline $5^{\text {th }}$ week & $1824.28^{\mathrm{a}}$ & $1944.50^{\mathrm{bc}}$ & $1875.65^{\mathrm{ab}}$ & $1978.40^{\mathrm{c}}$ & 2620 & $*$ \\
\hline $6^{\text {th }}$ week & $2473.25^{\mathrm{a}}$ & $2632.50^{\mathrm{b}}$ & $2548.95^{\mathrm{ab}}$ & $2635.45^{\mathrm{b}}$ & 39.33 & $*$ \\
\hline
\end{tabular}

(Significant $(\mathrm{P}<0.05)$ means under each class in the same column with different superscripts differ significantly)

Table.3 Serum lipid profile of broiler chickens fed lemongrass leaf meal diet

\begin{tabular}{ccccccc}
\hline \multicolumn{2}{c}{ Parameter } & \multicolumn{5}{l}{ LGLM levels } \\
\hline & $\mathrm{T} 1$ & $\mathrm{~T} 2$ & $\mathrm{~T} 3$ & $\mathrm{~T} 4$ & & \\
\hline$(0 \%)$ & $(0.5 \%)$ & $(1 \%)$ & $(1.5 \%)$ & $\mathrm{SE}$ & Sig. & \\
\hline Glucose $(\mathrm{mg} / \mathrm{dl})$ & $116.75^{\mathrm{a}}$ & $117.25^{\mathrm{a}}$ & $120.50^{\mathrm{ab}}$ & $124.75^{\mathrm{b}}$ & 1.96 & $*$ \\
\hline Cholesterol $(\mathrm{mg} / \mathrm{dl})$ & 136.50 & 134.50 & 133.75 & 130.00 & 3.18 & $\mathrm{NS}$ \\
\hline Triglyceride $(\mathrm{mg} / \mathrm{dl})$ & $130.50^{\mathrm{a}}$ & $136.75^{\mathrm{bc}}$ & $140.25^{\mathrm{c}}$ & $147.50^{\mathrm{d}}$ & 1.94 & $*$ \\
\hline HDL $(\mathrm{mg} / \mathrm{dl})$ & 86.25 & 89.75 & 90.25 & 92.75 & 2.77 & $\mathrm{NS}$ \\
\hline LDL $(\mathrm{mg} / \mathrm{dl})$ & 23.00 & 21.75 & 19.50 & 18.00 & 2.35 & $\mathrm{NS}$ \\
\hline LDL/HDL Ratio & 0.33 & 0.35 & 0.38 & 0.40 & 0.08 & $\mathrm{NS}$ \\
\hline A) Total Protein $(\mathrm{g} / \mathrm{dl})$ & 2.32 & 2.37 & 2.41 & 2.45 & 0.12 & $\mathrm{NS}$ \\
\hline Albumin $(\mathrm{g} / \mathrm{dl})$ & $1.50^{\mathrm{a}}$ & $1.54^{\mathrm{a}}$ & $1.55^{\mathrm{ab}}$ & $1.59^{\mathrm{b}}$ & 0.02 & $*$ \\
\hline b. Globulin $(\mathrm{g} / \mathrm{dl})$ & $1.31^{\mathrm{b}}$ & $1.29^{\mathrm{ab}}$ & $1.24^{\mathrm{a}}$ & $1.23^{\mathrm{a}}$ & 0.02 & $*$ \\
\hline
\end{tabular}

(Similar superscript do not differ significantly $(\mathrm{P}<0.05)$ from each other within a row the quantity of feed additive LLM increased.)

The differences in level of LDL cholesterol in $\mathrm{T}_{1}, \mathrm{~T}_{2}, \mathrm{~T}_{3}$ and $\mathrm{T}_{4}$ were non-significant. The $\mathrm{T}_{1}$ had highest LDL level followed by $\mathrm{T}_{2}, \mathrm{~T}_{3}$ and lowest level of LDL was found in $\mathrm{T}_{4}$. The
LDL / HDL ratio was highest in $\mathrm{T}_{4}$ in $1.5 \%$ level of lemongrass leaf meal and lowest in $\mathrm{T}_{1}$ control group. 
This proved the positive effect of lemongrass leaf meal in serum lipid profile. The differences in level of total protein in $\mathrm{T}_{1}, \mathrm{~T}_{2}$, $\mathrm{T}_{3}$ and $\mathrm{T}_{4}$ were non-significant. The $\mathrm{T}_{4}$ had highest level followed by $T_{3}, T_{2}$ and lowest level of total protein was found in $\mathrm{T}_{1}$.

The albumin was highest in $\mathrm{T}_{4}$ in of $1.5 \%$ level of lemongrass leaf meal and lowest value in $T_{1}$ in control group. The values of albumin clearly showed that all supplemented lemongrass leaf meal treatment is significantly higher values than control. The $\mathrm{T}_{1}(1.31$ $\mathrm{mg} / \mathrm{dl}$ ) had highest level followed by $\mathrm{T}_{2}, \mathrm{~T}_{3}$ and lowest level of globulin was found in $\mathrm{T}_{1}$.

Chioma et al., (2017) also reported the more or less findings and stated that the level of lemongrass (Cymbopogon citrates) leaf meal significantly decrease $(\mathrm{P}<0.05)$ in the serum glucose levels, cholesterol, total protein albumin levels and also globulin of the broiler diets.

The results of some other herbal feed additives are Al-Habori (1998) found that fenugreek and its extract reduced the levels of cholesterol, triglycerides, and low density lipoprotein (LDL-cholesterol) with no effect on high density lipoprotein (HDL-cholesterol).

This selective reduction in LDL-cholesterol results in the improvement of the ratio of HDL- cholesterol to LDL-cholesterol. Gaikwad (2018) found that the fenugreek seed powder increased the levels of glucose, HDLcholesterol, LDL-cholesterol; reduce the cholesterol, triglycerides, LDL and HDL ratio. Gujjarwar (2018) reported that serum glucose, triglyceride, HDL and LDL ratio levels were reduced when ginger powder was added in diet of broilers and increasing the HDL level in broilers.

This study indicated that supplementation of lemongrass leaf meal powder at the different levels of $0.5 \%, 1.0 \%$ and $1.5 \%$ in the broiler chick's diet. The inclusion of lemongrass leaf meal in broiler ration substantially decreased serum cholesterol, triglyceride and increased the glucose, total protein level and improved the LDL/HDL ratio. Hence, it is beneficial to use lemongrass leaf meal as a growth promoter or feed supplement in commercial broiler production.

\section{References}

Al-Habori M., Al-Aghbari A. M. and AlMamary. M. 1998. Effects of Fenugreek Seeds and its Extracts on Plasma Lipid Profile on Rabbits. Phytotherapy Res. Science. Vol. 12(5):572-575.

A. O. A. C. 1995. Official Methods of Analysis, $16^{\text {th }}$ ed. Association of Official Analytical Chemist, Washington D. C.

Chioma G. O., Akinsoyinu O. A., Olumide M. D., Ajayi O. A., Ndubuisi-Ogbonna L. C., Akinboye O. E., Adeyeye J. A., AyoBello T. and Afodu O. J. 2017. Carcass and Performance Characteristics of Broiler Chickens Fed with Cymbopogon citratus Leaf Meal as Alternative to Mycotoxin binder. International J. of Agril. Sci. 6(4):018-023.

Gaikwad B. S. 2018. Effect of Fenugreek (Trigonella Foenum-Graceum L.) Seed Powder as a Natural Feed Additive on Growth Performance of Broilers. M. Sc. (Agri.) Thesis, Submitted Marathwada Agriculture University, Parbhani.

Gujjarwar S. V. 2018. Effect of Ginger (Zingiber officinalis) Powder as a Natural Feed Additive on Growth Performance of Broilers. M. Sc. (Agri.) Thesis, Submitted Marathwada Agriculture University, Parbhani.

Khattak F., Ronchi A., Castelli P. and Sparks 
N. 2014. Effects of Natural Blend of Essential Oil on Growth Performance, Blood Biochemistry, Cecal Morphology and Carcass Quality of Broiler Chickens. J. of Poult. Sci. 93(6):132-137

Mmereole F. U. C. 2010. Effects of Lemmon

Grass (Cymbopogon citratus) Leaf Meal Feed Supplement on Growth Performance of Broiler Chicks. International $J$. of Poult. Sci. 9(12):1107-1111.Mukhtar A. M., Mohamed K. A., Amal O. A. and Ahlam A. H. 2012. Effect of Different Levels of Lemon Grass Oil (LGO) as a Natural Growth Promoter on the Performance, Carcass Yield and Serum Chemistry of Broiler Chicks. Egypt

Poult. Sci. 33 (1):1-7.

Oloyede O. I., 2009. Chemical Profile and Antimicrobial Activity of Cymbopogon citrates Leaves. J. of Natural Products. 2(23):98-103.

Sariozkan S., Konca Y., Kocaoglu B., Aktug M. K., Ozkan S. and Tugrul S. 2016. The Effect of Dietary Supplementation of Lemon Grass (Cymbopogon Citratus) on Performance, Carcass Quality, and Marketing of Quail
(Coturnix Coturnix Japonica). J. Scientific Works. Series C. Veterinary Med. 63(1):98-103.

Snedecor G. W. and Cochram W. G. 1982. Statistical Methods. $6^{\text {th }}$ Edition, Oxford and IBH Publishing co. Culcutta, Bombay and Delhi. 168-181.

Tiwari M. R., Jha P. K., Sah B., Kunwar G. and Jha A. K. 2018. Performance of Lemongrass (Cymbopogon citrates) Oil as Growth Promoter in Broiler. Bang. J. Anim. Sci., 47(2):85-91.

Weerasingha A. S. and Atapattu N. S. 2013. Effect of Fenugreek (Trigonella foenumgraecum $L$.) Seed powder on Growth Performance, Visceral Organ Weight, Serum Cholesterol Levels and the Nitrogen Retention of Broiler Chicken.

Tropical Agricultural Reserch. 24(3):289-295.

Zomrawi W. B., Atti K. A., Dousa B. M. and Mahala A. G. 2012. The Effect of Ginger Root Powder (Zingiber Officinale) Supplementation on Broiler Chicks Performance, Blood and Serum Constituents. Online Journal Anim. and Feed Reserch. Vol. 1(6):557-460.

\section{How to cite this article:}

Parade, A. K., B. M. Thombre, R. A. Patil, P. V. Padghan, S. S. Shinde and Meshram, P. B. 2019. Inclusion of Lemongrass (Cymbopogon citratus) Leaf Meal as a Natural Feed Additive for Evaluation Serum Lipid Profile of Broilers. Int.J.Curr.Microbiol.App.Sci. 8(10): 18351841. doi: https://doi.org/10.20546/ijcmas.2019.810.213 